(The 3rd ICBS-2013)

\title{
OBSERVATION REPORT OF THE ENDEMIC CHESTNUT-BELLIED HILL-PARTRIDGE (Arborophila javanica lawuana) IN TAHURA RADEN SOERJO, EAST JAVA
}

\author{
Heru Cahyono and Haris Eka Pramudhita \\ Malang Eyes Lapwing (MEL) Bird Study Group, Biology Department \\ Faculty of Mathematics and Science, State University of Malang, Jl. Semarang 5, Malang, Indonesia 65145. \\ Heru Cahyono: hc_garuda@yahoo.com
}

\begin{abstract}
Chestnut-bellied Hill-Partridge (Arborophila javanica) is an endemic species of Java, and also one of four endemic partridge species in the Greater Sunda islands. This species is constituted by three subspecies which differ in the color pattern of their head. The first reported sighting of Chestnut-bellied Hill-Partridge (Arborophila javanica lawuana) in Cangar is by Nijman in 2003, and for these past ten years the observation data has been inadequately obtained by local birdwatchers although its call is remarkable ; the call might be frequently heard by birdwatchers but got missed. Several information about this bird has been collected, including its sound recording that we used during observations. Observations were conducted around Cangar tourism object, particularly along the main road linking Pacet (Mojokerto) and Batu (Malang). The observations resulted in the data on its behavior and the best observation spot, that is in Lemahbang.
\end{abstract}

Key words: Chestnut-bellied Hill-Partridge, endemic bird, observation spot, Tahura Raden Soerjo.

\section{INTRODUCTION}

Chesnut-bellied Hill-Partridge (Arborophila javanica lawuana) is an endemic species of Java, and also one of four endemic partridge species in the Greater Sunda islands (Holmes, 1999). This species is constituted by three subspecies which differ in the color pattern of their head (Siebers, 1929), and Tahura Raden Soerjo is inhabited by the subspecies lawuana which is distributed between Lawu Mountain in the border of Central Java and all the way throughout East Java (Bartels, 1937). This bird lives in the forests upon the slopes of mountains and hills, and has been recorded to live between the elevation of 300-3000 meters (van Balen, 1992).

The first reported sighting of Chesnut-bellied Hill-Partridge (Arborophila javanica lawuana) in Cangar was by Nijman (2003), and for these past ten years the number of reported sightings by local birdwatchers has been very limited. This species is difficult to find, in spite of its remarkable sound: one or more birds produce a series of monotonous double soft squalls that goes louder and faster (MacKinnon et al., 2000). The sounds might have been heard by birdwatchers, but were frequently missed due to their never having seen the bird. Even though it is globally regarded as Not Threatened (BirdLife, 2001), but in the MaceLande category, it is regarded as Vulnerable (del Hoyo et al.,1994). The observations conducted in Tahura Raden Soerjo are aimed at understanding the behavior of this species, as well as finding its best watching spots. 


\section{MATERIALS AND METHODS}

One sighting was reported by Hana Putra Wicesa and Asief Abdi in the middle of 2011 at Watuondo; the given descriptions ascertained that the species seen was the Chestnutbellied Hill-partridge. Several information were then collected, including by playing a recorded sound to lure them, or at least to see if they would call in response. The observations were conducted around Cangar tourism object and the main road linking Batu and Pacet, in March 2012-June 2013. The first spot is in Watu Ondo, where this species was encountered for the first time while it was crossing the road.

\section{RESULTS AND DISCUSSION}

Several observations in the first spot employed recorded sounds, but the bird gave neither response nor appearance. Initial conclusion was that the spot is not the main foraging route of Chestnut-bellied Hill-partridge. The first successful sighting was on 29 April 2012,

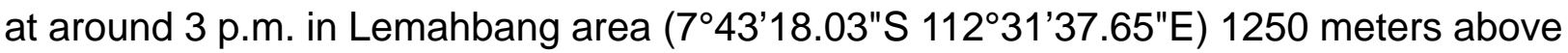
sea level, on a cloudy day. A pair of Chestnut-bellied Hill-partridge flew low for approximately 6 meters crossing the road passed by motor vehicles, then disappeared into the bushes. The next sighting happend in 22 January 2013 at 10.30 a.m. at the same spot, where a pair of Chestnut-bellied Hill-partridge was observed to be foraging on the mulches. The distance from the observers was 7-8 meters, and the weather was cloudy. The observation went on for almost an hour, maintained by carefully avoiding movements and playing recorded sounds. From this observation, the observers concluded that this species is not disturbed by the presence of the observers, yet they remain alert while keeping on foraging. When the recorded sound was played, they did not gave loud responses, but only produced few series of short monotonous soft double low sounds. The whole foraging area was 2 meters in diameter; each scratch was about 10-15 centimeters long, and about 20 centimeters wide. The observation The observersnt on for almost an hour until The observers had to stop due to the rain.

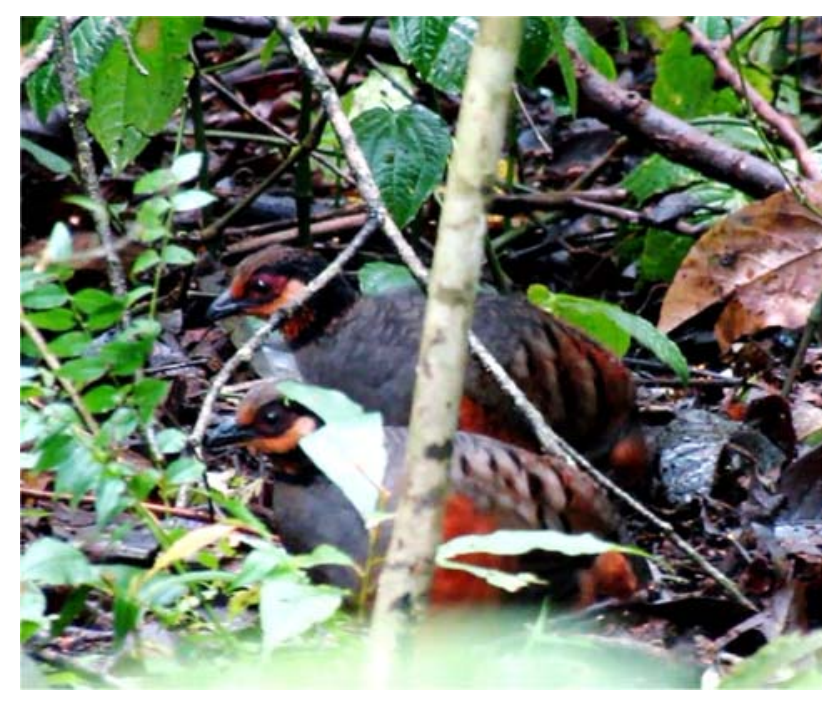

Figure 1. A pair of Chesnut-bellied Hill-partidge spotted in Lemahbang, Tahura Raden Soerjo, on 22 January 2013. Photo by Asief Abdi 
The third sighting took place on 24 January 2013 at 08.10 in Lemahbang. The observers encountered a pair of Chestnut-bellied Hill-partridge flew low in front of us, crossing the road for 6 meters and then foraged in the same location as before. The distance from the observers was about 7-8 meters away. The observers tried to avoid unnecessary movements, not to disturb and scare them away; this time, the observers managed to document their behavior. Similar to the previous observation, the observers played recorded sounds, and they still gave no response. At that time the observers concluded that this bird is sensitive to spontaneous movements and will remain nonchalant as long as the observers can minimize their movements. Moreover, it does not make loud sounds when it recognizes the observers' presence. The observers continued the observation and documentation until the birds were scared away by an approaching Leopard Cat (Prionailurus bengalensis).

During the observations conducted in Cangar (Goa Jepang-Jogging track) in December 2012, on 11 February 2013, 5 May 2013, and 10 June 2013, the observers only heard its sounds and only had one sighting in the last observation. This is due to the relatively high inclination of the ground and the dense vegetation dominated by bushes and tall trees which constricted the visibility. Even though the observers frequently heard its loud response in Cangar from a close distance, Lemahbang is still a more preferable location to observe this bird because of its wider range, better accessibility, and the fact this bird is often found foraging on the forest floor which makes it easier to document. During the several times the observers visited this spot and played its sound recording, the Chestnut-bellied Hill-partridge frequently responded from afar with a series of monotonous double squalls which goes louder and faster. Its sound had been heard during 9 a.m. to 4.20 p.m., either in sunny or cloudy weather.

Information in forms of photographs, videos, and sound recordings can be downloaded at www.fobi.co.web.id and www.xeno-canto.org.

\section{ACKNOWLEDGMENTS}

The authors would like to thank Ms. Dwi Listyorini, and also our fellow birdwatchers which have contributed to the production and publication of this paper: Imam Taufiqqurahman, Toni Artaka, Ahmad Yanuar, Ahmad Zulfikar Abdullah, Teguh Willy Nugroho, Ahmad Yanuar, Ahmad Zulfikar Abdullah, Teguh Willy Nugroho, Arif Budiawan, Muhammad Rizki Kurniawan, Riri Wiyanti Retnaningtyas, Bayu Hendra Prakosa, Dina Mayasari, Adityas Arifianto, and Swasti Prawidya Mukti.

\section{REFERENCES}

Holmes, D.A.1989. Status report on Indonesian galliformes. Kukila 4:133-143.

Siebers, H.C.1929. Neue Vogelrasse aus dem Indo-Australischen Gebiet. Treubia 11:149153.

Bartels, M.1937. Eine neue Rasse von Arborophila brunneopectus aus Java. Treubia 16: 321-322

van Balen, S.1992. Distribution,status and conservation of the forest partridges in the Greater Sundas (Indonesia) with special reference to the Chestnut-bellied Partridge (Arborophila javanica). Gibier Faune Sauvage 9: 561-569. 
Nijman, V. 2003. Distribution, habitat, use and conservation of the endemic Chesnut-bellied Hill-Partridge (Arborophila javanica) in Fragmented forest of Java, Indonesia. Emu. 103: 133-140.

MacKinnon, J., K. Phillipps, and B. van Balen. 2000. Burung-burung di Sumatera, Jawa, Bali dan Kalimantan. Pustlitbang Biologi LIPI and BirdLife International Indonesia Programme, Jakarta.

BirdLife International. 2001. Threatened Birds of Asia-the BirdLife International Red Data Book. Birdlife International, Cambridge.

del Hoyo, J., A. Elliott, and J. Sargatal. 1994. Handbook of the Birds of the World 2. Lynx Edicions, Barcelona.

Edwards, D. 2009. Call voice Chesnut-Bellied Partridge. Accessed from www.xeno-canto.org. 